\title{
PROPOSAL OF TECHNOLOGY OF TRAIN COMPOSITION IN KOŠICE STATION
}

\author{
Abstract. The rolling stock, its operation and maintenance are one of the problems that concern every rail carrier. \\ Appropriate scheduling of wagons composition, its circulation and maintenance is not simple, especially if the carrier \\ has a low number of locomotives and wagons used every day. In this paper is proposed a technology of wagons \\ composition in the station Košice. \\ Keywords: railway transport, operation, the composition of the train \\ Lukáš Čechovič $\check{1}^{1}$ \\ ${ }^{1}$ Faculty of Operational and Economics of Transport and Communications, University of Žilina, \\ Univerzitná 8215/1,01026 Žilina; +421/41 513 3434; lukas.cechovic@fpedas.uniza.sk \\ Vladislav Zitrický ${ }^{2}$ \\ ${ }^{2}$ Faculty of Operational and Economics of Transport and Communications, University of Žilina, \\ Univerzitná 8215/1,01026 Žilina; +421/41513 3406; vladislav.zitricky@fpedas.uniza.sk
}

\section{Introduction}

The gradual development and growth of the rail transport market have allowed new, private carriers to enter the market.

The liberalization of rail transport and its legislation have brought the benefits of these carriers to the market. The entry of private carriers into railway infrastructure can lead to an increase in the quality of transport and the services provided, as well as an increase in competitiveness. The arrival of new transport operators on the rail transport market has mainly contributed to reliable, more comprehensive and cost-effective services.

The improvement of these services brought by new competitors is leading to greater customer interest. This contribution of new services, as well as increasing the comfort and safety of transport, will cause competition among carriers.

The carrier's interest is to maintain and expand their performance and maximize profit. However, in the transport market, it has to face competition between different carriers of all modes of transport as well as between carriers of the same mode of transport.

\section{Impact of liberalization on the transport market}

One of the possibilities of the global transport market and promotion of the improvement of railway transport services is liberalization, i.e. opening of the transport market, entry of carriers on the market on nondiscriminatory terms.

The EU rail transport market was long inaccessible to the private sector. The promotion of liberalization was solved by acceptance through the adoption of legislative measures designed to lead to fair, non-discriminatory competition and the rail services market. The White Paper and the first Directives have gradually established a solid basis for liberalizing rail transport.

The liberalization of transport market brings various effects, which in the context of the assessment of synergies can affect in different ways the company, a customer as such, and transport undertakings operating on the railway transport market as well.

Private railway passenger operators want to increase their market share together with national railway passenger transport companies, therefore, the quality of passenger transportation is getting higher, which positively influences the attractiveness of railway passenger transport.

\section{Analysis of the current composition of carrier's trains}

The simultaneous composition of trains of Regiojet company divides into two branches. The southern branch, which includes all the trains that are operated on the lines Brno, Bratislava, and Vienna and the northern branch, which includes lines connecting Prague with Havírov, Opava, Návsí and Košice

The composition of trains subject to specific carrier criteria. One of the main criteria is to create a kind of basic trunk, or a basic set of ranked wagons that will form the basis of every carrier trainset and will offer all kinds of tariff classes. Care must be taken to accommodate wagons with kitchen, children's compartments and appropriate arrangements of business, standard, astra and low-cost tariff classes offered by the carrier.

The offered service on the trains can be divided into several tariff classes of the carrier, as the service in these classes differs.

The carrier offers a selection of the following classes:

- Business;

- Relax;

- Standard;

- Astra;

- low cost;

- $\quad$ sleeping car;

- baby compartment;

- $\quad$ silent compartment; 


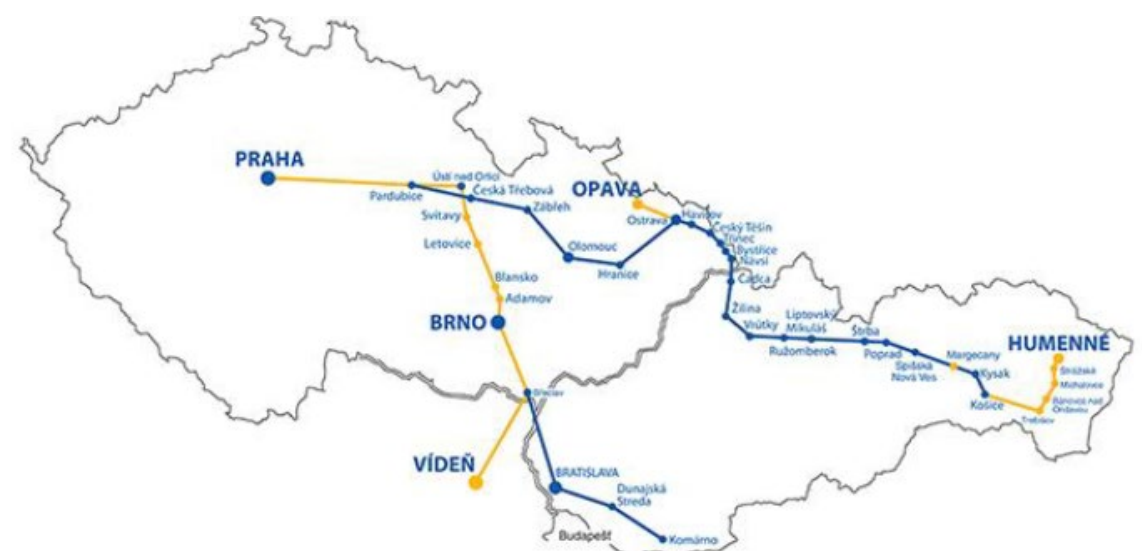

Fig. 1. North and South branches of carrier Regiojet

\section{Business class}

In this class, priority is given to serving the clients which is one of the other benefits of pleasant transport. Throughout the journey on board is staff available at any time to satisfy your wishes - whether it's about providing information or ordering from a menu.

\section{Relax}

There is a steward in every two carriages for customer satisfaction, providing on-board services. At the Relax service from the cart is not provided, quality refreshments are provided during the journey at an affordable price

\section{Standard class}

On-board services are also provided by the steward. Operation from the cart at the Standard tariff is provided after the departure from Prague; from Kysak, OstravaSvinov and from Brno (in the direction of Prague); free illy coffee and a refreshment order from our menu follows $40-60$ minutes after servicing from the cart, may be adapted to the occupancy of the wagon.

Offers:

- adjustable leather or plush seats;

- compartment for babies, silent compartment;

- WIFI.

\section{Astra wagon}

The benefits of the ASTRA wagon will be appreciated by those who want to work or have fun by watching the fun portal. When booking a ticket, you choose a place with a monitor or a practical table. Board service is similar to the aircraft from the cart, which guarantees fast service without unnecessary disturbance. After service from the cart, you can order from the onboard menu packed and fast-servicing snacks.

Offers:

- adjustable seats with built-in LCD multimedia screens;

- large-carriages for 80 people ensuring relax for work and entertainment;

- socket and USB for each seat;

- WIFI.

\section{Low cost}

It offers a simple, calm and undisturbed journey at the lowest price that does not offer any service.

Offers:

- plush unstretchable seats;

- large-carriages for 80 people;

- undisturbed travel at the lowest price;

- free bicycle transport;

- WIFI.

\section{Wagons-lits}

Passengers traveling with sleeping wagons can enjoy full sleep on a bed or a couchette. Compartment with a bed or with couchette is different from the number of beds and the quality of the beds. Compartment with beds provide better privacy ( 3 persons), each has a dressed bed and an independent seat. Seats in couchette compartment (6 persons) are layout before the silent hours with the help of the crew. The bed-clothes are secured by passengers alone, from the prepared packages.

Offers:

- sleeping cars are available in the RJ 1021 PragueKošice and RJ 1020 Košice-Prague;

- for purchase: hygienic package $3,20 €$ security luggage lock 1,20€;

- WIFI.

\section{Standard/compartment for babies}

Compartment for babies is designed for children and parents to ensure a comfortable trip.

Offers:

- large-capacity compartment, 6 adult seats and children's stools (2-6 years);

- merry pictures, toys, Žlutík magazine, games, television with children's films;

- reservation of seats no. 61-66 at Standard rate;

- WIFI. 


\section{Silent compartment}

The place in this compartment can be booked in Standard and Business class, which provides customers a comfortable and undisturbed journey.

Offers:
- limited use of mobile phones, loud listening to music, and more;

- not recommended for children under 15 years of age;

- WIFI.

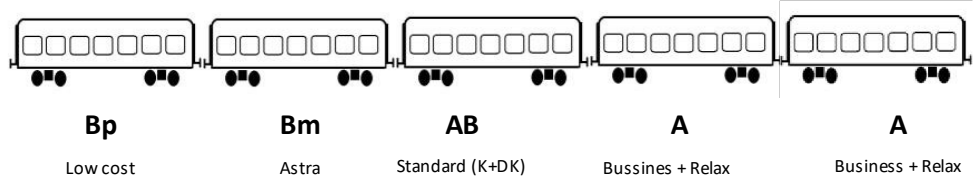

Fig.2. The tribal composition of five wagons

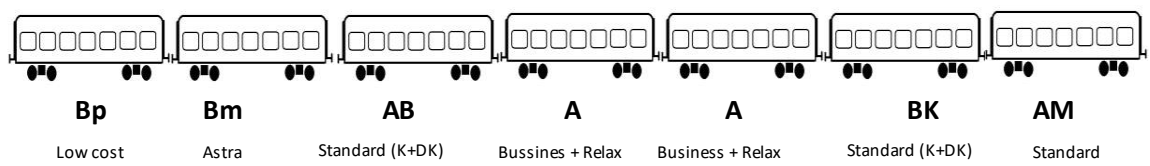

Fig. 3. The tribal composition of seven wagons

In the following table, the current state of the carrier's fleet is processed according to individual types of wagons, their total number and backup wagons for possible repair and maintenance.

Table 1. Overview of the current state of the vehicle fleet of Regiojet

\begin{tabular}{|c|c|c|}
\hline Type of wagon & Quantity & $\begin{array}{c}\text { Backup } \\
\text { wagons }\end{array}$ \\
\hline A & 38 & 2 \\
AB & 16 & 0 \\
Am & 13 & 1 \\
Bm & 10 & 0 \\
Bp & 14 & 1 \\
Bk & 14 & 0 \\
B & 6 & 2 \\
AS & 2 & 0 \\
Bc & 14 & 1 \\
\hline Total & 127 & 7 \\
\hline
\end{tabular}

\section{Proposal for the technology of train composition in Košice station}

This section describes the technology of train composition in the Košice railway station and the circulations of individual trains. Due to the deficient number of wagons of the carrier's fleet, it was necessary to process the wagon circulation on individual trains so that they were fully utilized, therefore it is necessary to divide the train sets and compose the wagons to the specified directions of the northern branch taking into account the necessary transport capacity on the train.

A similar theme was also addressed by Ing. Dlugoš, where in his thesis on the basis of the current operating station, resolved with the circulations of trainsets on the line Komárno - Dunajská Streda - Bratislava but for the engine units, therefore the proposal in this paper solves the circulations of wagons.

a) RJ 409/400 (to Vrútky, to Prague goes as train 1008/1011

- 1011 - arrival to Košice station 22:43, after that displacement to refill water and cleaning;

- trainset is consist of 162 locomotive and seven wagons;

- subsequent departure at 03:45 as $\mathbf{1 0 0 8}$ to Prague station.

b) $\mathrm{RJ}$ train 1021/1012 (1121)

- arrival to Košice at 06:14 as 1021 / subsequent departure at 07:45 from Košice station as 1012;

- train 1021 consist of (5) 6 couchette wagons and 5 8 seat wagons ( $\max .13$ wagons in trainset);

- trainset 1021 is divided on 3 parts after arrival;

- group of wagons on 1021 behind locomotive (3 wagons) goes on track n.4a to shut down;

- group of wagons in the middle 1021 (1 seat wagon and 3-4 couchette wagons) goes as train 1121 to Humenné station with locomotive 750;

- group of wagons in the end of train (4-7 wagons) goes on train set 1012;

- at the time of ordered shunt, backup of ZSSK make a shunt of shutted down wagons from train 1003 (13 wagons) to train 1012 - this wagons are shutted down according to capacity demand;

- train 1012 is consist of 7 seat wagons with 162 locomotive to Praha station. 


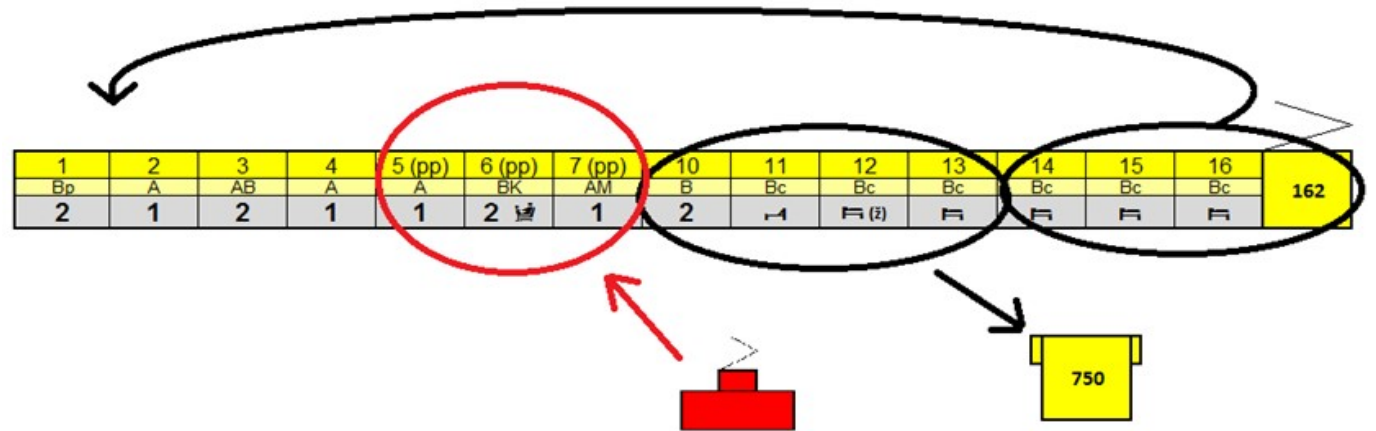

Fig. 4. Dividing the train set 1021 into 3 parts

\section{c) $\mathrm{RJ} 1003$ or $1120 / 1020$}

- the arrival of train 1003 at 15:43 which consist of 7 wagons / then the whole train set is shut down and goes to refill water and cleaning;

- the front part of train set 1003 will shut down with a locomotive of Regiojet on track n.15 (1-3 wagons);

- train set 1020 is consist of 3 parts:

- group 1 - at the end of train 1020 are wagons from train 1003 (part of the train set 1003 was shut down on track n.15);

- group 2 - is situated in the middle of train set 1020 is consist of wagons from the train set 1021 from $4 a$ track;

- group 1 and 2 - shunt from track n.4a with wagons from the train set 1021 and shut down of wagons from 1003 to track $n .15$ will be done before train 1120 from Humenné station arrive;

- group 3 - wagons behind locomotive 162 of train 1020 are made up of the train set 1120. After the arrival of train 1120, groups 1 and 2 will be pushed to train 1020 .

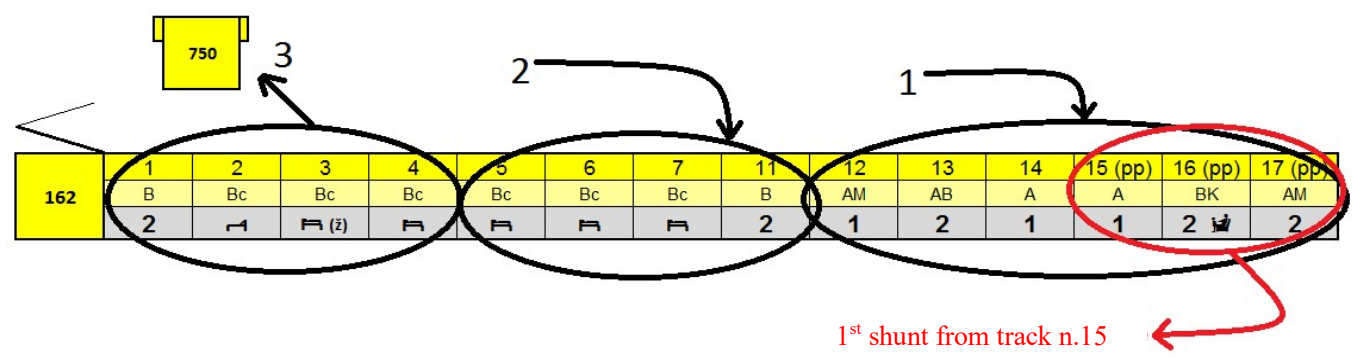

Fig. 5. The composition of the train set 1020

\section{Conclusion}

This proposal in this paper presents the method of compositing wagons to individual trains of the carrier and the technology of composition on the sections of the northern branch. The suggestion for the solution arose at the initiative of the railway carrier Regiojet operating trains in this part of the ŽSR railway network.

The composition of the carrier's fleet also contributes to the quality of transport that we can consider to be one of the main components of rail passenger transport. Operation and ownership of such a quantity of railway vehicles require its tax, where care must be taken not only for its use in service but also for its maintenance. When analysing the fleet and its current state, we conclude that the carrier has an insufficient number of wagons and therefore it is difficult to operate as many sections at once. This proposal was prepared for ŽST Košice, with the current number of wagons, where for the trains of the carrier this station is departure station and arrival station.

\section{References}

Čechovič, L. 2018 Návrh radenia vlakov dopravcu Regiojet. / The proposal of the trains composition of Regiojet carrier/. Diploma thesis. Žilina: Žilinská univerzita, 72 p.

Dlugoš, M. 2017 Optimalizácia vlakových súprav Regiojet, a.s. na trati Komárno - Dunajská Streda - Bratislava hl.st.. / Optimization of train sets Regiojet, a.s. on the line Komárno - Dunajská Streda - Bratislava hl.st./. Diploma thesis, Žilina: Žilinská univerzita, $74 \mathrm{p}$.

Gašparík, J., Šulko, P. 2016 Technológia železničnej dopravy, Líniové dopravné procesy. / Railway transport technology, Line transport processes/. Žilina: Žilinskeá univerzita, 384 p., ISBN 978-80554-1171-2.

Panák, M. et al. 2017 Synergies of the Liberalization of the Railway Transport Market. In: 18th International Scientific Conference, LOGI 2017, Ceske Budejovice. Vol. 134, (2017). ISSN 2261236X

Záhumenská, Z. et al. 2018 Position of railway passenger transport companies on current liberalized transport market. In: 10th International Scientific Conference Horizons of Railway Transport, University of Zilina, Vol. 235, (2018). ISSN 2261236X 